\title{
MEASUREMENT OF ALIGNMENT LEVELS BETWEEN ORGANIZATIONAL AND INFORMATION TECHNOLOGY TO INFORMATION (CASE STUDY ON ACADEMY OPERATIONAL DIRECTORATE, XYZ UNIVERSITY)
}

\author{
Endi Putro \\ Information System Department, Technic and Computer Science Faculty, \\ Krida Wacana Christian University \\ Jakarta, Indonesia \\ endiputro@ukrida.ac.id
}

\begin{abstract}
Directorate of Academy Operations (DAO) of XYZ University functions to support the ongoing academic process. DAO activities supported by information technology (IT) include: manage student data, manage teaching data, and manage lecturer data. Activities conducted in this research study was to assess the current alignment between IT and business strategy of DAO using the COBIT 4.1. The result shows we can conduct an analysis using the COBIT 4.1 framework to formulate strategic recommendations related to the use of IS/IT by DAO. The purpose of this research is to know the alignment strategic between business strategic of DAO and information technology. Organizations use information technology as a tool to achieve purpose. Often information technology is not participated as strategic tool to achieve organization purpose. Or in other words, organization has different purpose from information technology.
\end{abstract}

Keywords: alignment, organization, technology information

\section{INTRODUCTION}

Information Technology Governance Institute (ITGI) is an independent institution that issued guidance on how information technology is managed for the benefit of the business.

According to ITGI (2003), the alignment between business strategy and information technology (IT) focuses on efforts to ensure a relationship between business plans with IT; including defining activities, organizing maintenance, validating the IT value and aligning IT with the organization's operational.

Furthermore, ITGI also mentions that a key element of IT governance is the alignment of business strategy and IT. XYZ as a university, conducting its activities primarily in education. The ability of an institution or organization to manage its business processes determine the capability to realize the vision and mission. Academic Services at XYZ University is managed by a directorate called the Directorate of Academy Operations. Data coverage that must be processed and managed by DAO, would be a challenge. One solution to address this challenge is the investment in IT

IT investments should provide value to the business organizations (ITGI, 2006). Organization submits to the IT department on all matters of data. Organizations do not do planning in managing data. There is no alignment between business and IT strategy, there is no impact on IT to support the business strategy.

\section{PROBLEM FORMULATION}

How Directorate of Academic Operations and Information Technology can be aligned with each other in order to deliver the benefits of information technology investments for the organization?

\section{ALIGNMENT OF BUSINESS AND INFORMATION TECHNOLOGY}

To determine what kind organization will be established in the future, then the organization formulates: Vision, Mission, Objectives, and Strategies achievements. In order to implement their vision operationally, then it is translated into Mission. The mission of the organization is achieved by determining the organization's goals. To achieve organizational goals, then strategies to achieve those objectives are arranged.

Business processes are the operational activities of the organization. To achieve the strategic objectives of the organization, business processes must be established to consider the four components of the strategic business (Vision, Mission, Objectives, and Strategies). Organization's business processes is the implementation of strategic business 
organization. Strategic business will be achieved by running the organization's business processes.

Information technology is automation process. Organization automation process is in the business process level. If the business processes supported by information technology and addresses the needs of the organization to achieve the business strategy, it is said that organization's business is aligned to information technology.

\section{DIRECTORATE OF ACADEMY OPERATIONS}

DAO define business processes in a service procedure to students. DAO has 13 service procedures as follows (Prosedur UAA, 2013):

1. Procedure of Transfer Students Admission

2. Procedure of Student's Leave Registration

3. Procedure of Student's Study Plan

4. Procedure of Student's Resignation

5. Procedure of Course Preparation

6. Procedure of Class Execution

7. Procedure of Exam Preparation

8. Procedure of Exam Execution

9. Procedure of Registration and Supplementary Exam Preparation

10. Procedure of Processing Value

11. Procedure of Thesis Registration

12. Procedure of Graduation and Graduation Documents

\section{INFORMATION TECHNOLOGY GOVERNANCE}

According to ITGI (2007), the key to the organization in order to maximize the role of IT is through the implementation of IT governance. As seen in the conceptual model (Figure 1), there are five areas that are the focus of IT governance. The five areas are Alignment Strategy, Value Delivery, Risk Management, Resource Management and Performance Measurement. This paper focuses on the areas of Strategic Alignment.

\section{COBIT 4.1 FRAMEWORK}

COBIT 4.1 (Control Objectives for Information and related Technology) is a standard for controlling information technology, developed and promoted by the IT Governance Institute. COBIT 4.1 is designed as an IT governance tool that helps understand and manage the risks and benefits associated with information and IT. Figure 2 shows the model of COBIT 4.1 framework.
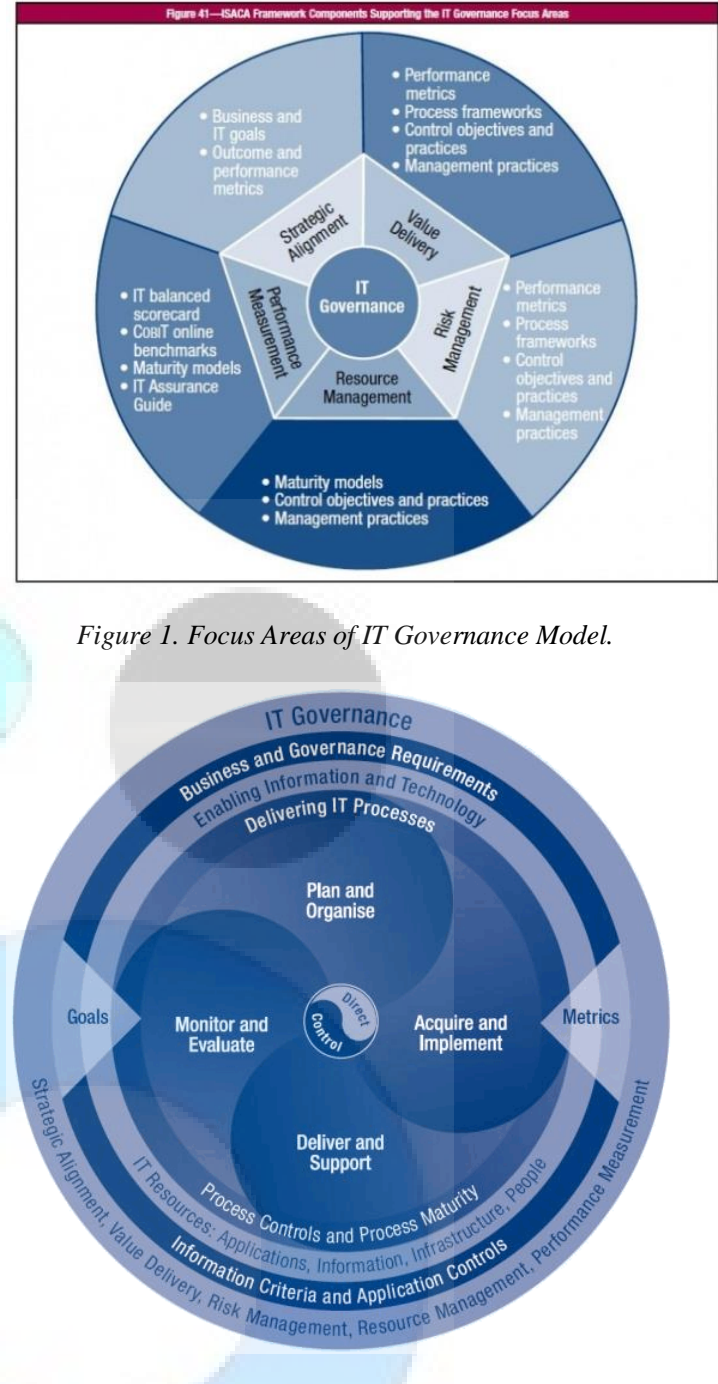

Figure 2. Model of COBIT 4.1. Framework

COBIT 4.1 framework consists of four domains as follows: Plan and Organise (PO), Acquire and Implement (AI), Deliver and Support (DS), dan Monitor and Evaluate (ME). Domains consist of processes. There are 10 processes for PO (PO1PO10), 7 processes for AI (AI1-AI7), 13 processes for DS (DS1-Ds13), and 4 processes for $\mathrm{ME}$ (ME1-ME4). Overall there are 34 processes.

\section{MODEL MATURITY}

Measuring the level of alignment between business and IT uses COBIT 4.1 Maturity Models. COBIT 4.1 Maturity Model is a model for the control of IT processes that contain development of assessment methods, so that the organization has a quantification level of 0 to 5 . Figure 3 describing the definition of each level of maturity. Level 0 indicates management are not applied at all. Level 1 indicates processes are ad hoc and disorganized. Level 2 indicates processes follow a regular pattern. Level 3 
indicates processes are documented and communicated. Level 4 indicates processes are monitored and measured. Level 5 indicates best practices are followed and automated.

The level of alignment indicates how much do IT processes support the achievement of strategic business objectives (Rouyet, J.I., dkk, 2010). Level 0 indicates the process of IT does not yet support the strategic objectives of business. The greater the degree of alignment indicate greater IT support to the achievement of business goals.

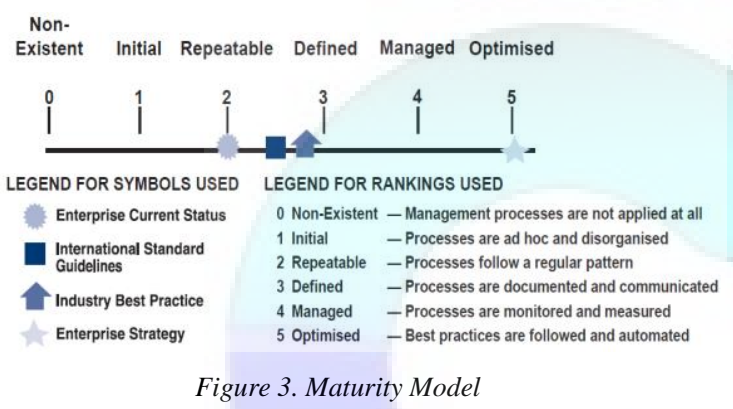

\section{METHODOLOGY}

Recommended COBIT 4.1 processes in Strategic Alignment area are: PO1-PO10, AI1, AI2, AI4, AI7, DS1, DS3, DS4, DS7, ME1, ME3, and ME4. Each process has a maturity level 0-5.

Research data were obtained from interviews with the director of academic operations. The processes in the areas of strategic alignment are converted into question. There are 19 questions to the director of academic operations. Then giving weight an answer by adjusting the level of maturity. Weighting maturity level is guided by management guidelines (ITGI, 2007). For example: question to process PO1 proposed. After obtaining the answer then it is weighted, the result of a maturity level was 0 . So forth was done for subsequent processes. The results obtained by calculating the maturity level of the average level of process maturity.

\section{RESEARCH RESULT}

Data were obtained from Director answers of Academic Operations Directorate consisting of nineteen questions. The research data was a quantitative value or maturity level that has intervals from zero to five for each answer. Data processing was done by calculating the maturity level of each domain. Maturity level of each domain is calculated from the average value of the processes in the domain.

Here are the results of each process maturity level (ML) and grouped into their respective domains.
Table 1. PO Domain

\begin{tabular}{|c|c|c|c|}
\hline No & Process & Process Name & ML \\
\hline 1 & PO1 & $\begin{array}{l}\text { Define a Strategic } \\
\text { Information } \\
\text { Technology Plan }\end{array}$ & 0 \\
\hline 2 & $\mathrm{PO} 2$ & $\begin{array}{l}\text { Define the Information } \\
\text { Architecture }\end{array}$ & 1 \\
\hline 3 & PO3 & $\begin{array}{l}\text { Determine } \\
\text { Technological } \\
\text { Direction }\end{array}$ & 2 \\
\hline 4 & PO4 & $\begin{array}{l}\text { Define the Information } \\
\text { Technology } \\
\text { Organisation and } \\
\text { Relationships }\end{array}$ & 2 \\
\hline 5 & PO5 & $\begin{array}{l}\text { Manage the } \\
\text { Information } \\
\text { Technology Investment }\end{array}$ & 1 \\
\hline 6 & PO6 & $\begin{array}{l}\text { Communicate } \\
\text { Management Aims and } \\
\text { Direction }\end{array}$ & 3 \\
\hline 7 & PO7 & $\begin{array}{l}\text { Manage IT Human } \\
\text { Resources }\end{array}$ & 1 \\
\hline 8 & PO8 & Manage Quality & 1 \\
\hline 9 & PO9 & $\begin{array}{l}\text { Assess and Manage IT } \\
\text { Risks }\end{array}$ & 0 \\
\hline 10 & PO10 & Manage Projects & 0 \\
\hline & & $\sum \mathrm{PO}$ & 11 \\
\hline
\end{tabular}

Maturity level of Plan and Organise Domain was determined by counting:

$$
\text { Maturity Level } \mathrm{PO}=\sum \mathrm{PO} \div n
$$

$n$ was a the number of the PO that determined by the strategic alignment COBIT. Maturity Level Results PO $=11 \div 10=1.1$

Table 2. AI Domain

\begin{tabular}{|c|c|c|c|}
\hline No & Process & Process Name & ML \\
\hline 1 & AI1 & $\begin{array}{ll}\text { Identify } & \text { otomated } \\
\text { solutions }\end{array}$ & 1 \\
\hline 2 & AI2 & $\begin{array}{l}\text { Acquire and Maintain } \\
\text { Application Software }\end{array}$ & 1 \\
\hline & & $\sum \mathrm{AI}$ & 2 \\
\hline
\end{tabular}

Maturity Level Results AI $=2 \div 2=1$

Table 3. DS Domain

\begin{tabular}{|l|l|l|c|}
\hline No & Process & Process Name & ML \\
\hline 1 & DS1 & $\begin{array}{l}\text { Define and Manage } \\
\text { Service Levels }\end{array}$ & 1 \\
\hline 2 & DS3 & $\begin{array}{l}\text { Manage Performance } \\
\text { and Capacity }\end{array}$ & 0 \\
\hline 3 & DS4 & $\begin{array}{l}\text { Ensure Continuous } \\
\text { Service }\end{array}$ & 1 \\
\hline 4 & DS7 & Educate and Train & 1 \\
\hline
\end{tabular}




\begin{tabular}{|c|r|r|r|}
\hline & \multicolumn{1}{|c|}{ Users } & \\
\hline & & $\sum$ DS & 3 \\
\hline \multicolumn{3}{|c|}{ Maturity Level Results DS $=3 \div 4=0.75$}
\end{tabular}

Maturity Level Results DS $=3 \div 4=0.75$

Table 4. ME Domain

\begin{tabular}{|l|l|l|c|}
\hline No & Process & Process Name & ML \\
\hline 1 & ME1 & $\begin{array}{l}\text { Monitor abd Evaluate } \\
\text { IT performance }\end{array}$ & 1 \\
\hline 2 & ME3 & $\begin{array}{l}\text { Ensure compliance with } \\
\text { external requirements }\end{array}$ & 1 \\
\hline 3 & ME4 & Provide IT Governance & 0 \\
\hline & & $\sum$ ME & 2 \\
\hline
\end{tabular}

Maturity Level Results ME $=2 \div 3=0.67$

Maturity level for the whole process is the maturity level alignment between the business goals of DAO with information technology. Maturity Level DAO $=18 \div 19=0.95$ or rounded to 1 .

Plan of the maturity level that will achieved by DAO in the future is level 2 (Repeatable but Initiative). The maturity level 2 has a state where processes have developed to the stage where similar procedures are followed by different people undertaking the same task. There is no formal training and communication of standard procedures, and responsibility is left to the individual. There is a high degree of reliance on the knowledge of individuals and, therefore, errors are likely (ITGI, 2007).

\section{DISCUSSION}

To govern effectively, IT is ordered into the responsibility domains: plan, build, run and monitor (COBIT, 2013). COBIT Framework calls on processes: PO, AI, DS, and ME. The processes that need to be upgraded to level 2 are processes that have levels 0 and 1 .

\subsection{Processes of PO}

Processes that have Level 0 and 1 are PO1, PO2, PO5, PO7, PO8, PO9, and PO10. Here's the process that needs to be done in order to achieve level 2 .

Table 5. Processes of PO

\begin{tabular}{|c|l|}
\hline Process & Increasement process \\
\hline PO1 & $\begin{array}{l}\text { Define } \\
\text { technology that achieve organization } \\
\text { objective }\end{array}$ \\
\hline PO2 & $\begin{array}{l}\text { Use framework enterprise architecture } \\
\text { to develop organization }\end{array}$ \\
\hline PO5 & $\begin{array}{l}\text { Calculate the budget for IT } \\
\text { development and the benefits of the }\end{array}$ \\
\hline
\end{tabular}

\begin{tabular}{|c|l|}
\hline & development \\
\hline PO7 & $\begin{array}{l}\text { Hiring and managing human } \\
\text { resources who understand the } \\
\text { performance of IT in support of the } \\
\text { achievement of DAO goals }\end{array}$ \\
\hline PO8 & $\begin{array}{l}\text { Develop IT to monitor the quality of } \\
\text { the services performed DAO }\end{array}$ \\
\hline PO9 & $\begin{array}{l}\text { Assess and Manage IT Risks since IT } \\
\text { is developed }\end{array}$ \\
\hline PO10 & $\begin{array}{l}\text { Define Team and develop IT as a } \\
\text { project }\end{array}$ \\
\hline
\end{tabular}

PO in the COBIT framework provides strategies and tactics, and identifying how IT best contributes to the achievement of business goals. The realization of the DAO's vision needs to be planned, communicated, and managed for multiple perspectives. IT in DAO was not the result of defining process of the IT strategic plan.

Information Systems Applications in DAO was still limited to resolve operational issues, such as: inputting student's grades, calculating student's GPA, and so on.

Information System Application has been there before formed DAO. That means the business strategic objectives of DAO compiled after information systems application used DAO. So that there is no significant correlation between strategic objectives with IT support DAO.

Disconnect between strategic business and IT did not result in the achievement of strategic business DAO, which was not achieved (DAO, 2013):

- Vision: Provide effective and efficient services

- Mission: Provide excellent services support to the academic community

- Objective: The efficiency of the academic process, a fast and accurate service, accurate academic data.

\subsection{Processes of AI}

Processes that have Level 0 and 1 are AI1 and AI2. Here's the process that needs to be done in order to achieve level 2.

Table 6. Processes of AI

\begin{tabular}{|l|l|}
\hline Process & Increasement process \\
\hline AI1 & $\begin{array}{l}- \text { Make on line student service } \\
- \text { Interactive services for lecturers }\end{array}$ \\
\hline AI2 & $\begin{array}{l}\text { Evaluation of the utilization of } \\
\text { existing information systems }\end{array}$ \\
\hline
\end{tabular}

AI in the COBIT framework aims to realize the IT strategy. So that IT solutions need to be identified, developed, and implemented and 
integrated into business processes.

DAO defines thirteen procedures for doing business. Furthermore, in technical language, DAO procedures referred to as business processes. More than $50 \%$ of DAO's business processes is not supported by information system applications. Some business processes supported information system applications was the procedures: Student's Study Plan, Course Preparation, Class Execution, Processing Value, and Thesis Registration.

DAO strategic goals: efficiency, fast service and precise, and accurate information will not be achieved if business processes were not supported by the information system applications. If the destination was used as an indicator of benefit, then IT was used DAO has not provide benefits for the achievement of goals.

\subsection{Processes of DS.}

Processes that have Level 0 and 1 are DS1, DS3, DS4, and DS7. Here's the process that needs to be done in order to achieve level 2 .

Table 7. Processes of DS

\begin{tabular}{|l|l|}
\hline Process & Increasement process \\
\hline DS1 & $\begin{array}{l}\text { - Prepare the benefit od application } \\
\text { report } \\
\text { whether the benefits in accordance } \\
\text { with IT investments }\end{array}$ \\
\hline DS3 & $\begin{array}{l}\text { - Prepare individuals to take } \\
\text { advantage of IT applications as } \\
\text { optimal as possible } \\
\text { In connection with the limited } \\
\text { storage and IT capacity. }\end{array}$ \\
\hline DS4 & $\begin{array}{l}\text { Prepare a report format that has been } \\
\text { done by IT to customers to ensure } \\
\text { continuity of service }\end{array}$ \\
\hline DS7 & $\begin{array}{l}\text { Educate and Train Users to ensure } \\
\text { goal's achievement. }\end{array}$ \\
\hline
\end{tabular}

DS domain associated with the implementation of the required services. Implementation of IT support for DAO was the application of information systems. This application provides services to students and lecturer.

Information systems applications that used DAO was still limited generate transactional information. From the results of transactional information, there are two issues, as follow:

1. Not all business processes was supported information system applications

2. Information processing results inaccurate data

All IT processes need to be managed and controlled regularly from time to time to the accuracy of the data. DAO must determine the core business. From the core business, conducted monitoring and evaluation process.

\subsection{Processes of MS}

Processes that have Level 0 and 1 are MS1, MS3, and MS4. Here's the process that needs to be done in order to achieve level 2 .

Table 8. Processes of MS

\begin{tabular}{|l|l|}
\hline Process & Increasement process \\
\hline ME1 & $\begin{array}{l}\text { - Setting up a monitoring report } \\
\text { format of information services } \\
\text { - Setting up an evaluation report } \\
\text { format of information services } \\
\text { - The monitoring and evaluation of } \\
\text { information services required by } \\
\text { users }\end{array}$ \\
\hline ME3 & $\begin{array}{l}\text { Setting up user input format for the } \\
\text { service information that has been } \\
\text { obtained }\end{array}$ \\
\hline ME4 & $\begin{array}{l}\text { setting up procedures to manage IT } \\
\text { by adopting IT governance } \\
\text { framework }\end{array}$ \\
\hline
\end{tabular}

DAO core business has not been defined. Monitoring and evaluation has not been conducted on established DAO procedures. For all the domains, ME was a domain that has the lowest maturity level.

The graphs shows a declining level trend successive of PO, AI, DS, and ME, as shown in Figure 4.1. Domain PO affects AI, domain PO and $\mathrm{AI}$ affects the DS, and Domain PO, AI, and DS affects ME. PO: Giving direction to AI services and solutions to the DS, AI: Preparing solutions for AI and provide services for DS, DS: Getting a solution and make the DS can be used by end users, ME: Monitor and evaluate all processes on target.

The calculation results of maturity levels for the DAO PO, AI, DS, and ME were: 0.947 or rounded 1. Maturity level of alignment between the organization and IT is 1, this indicates DAO has known and experienced problems in managing and controlling information and the issue needs to be addressed. If there was a problem there was no standard process completion. 


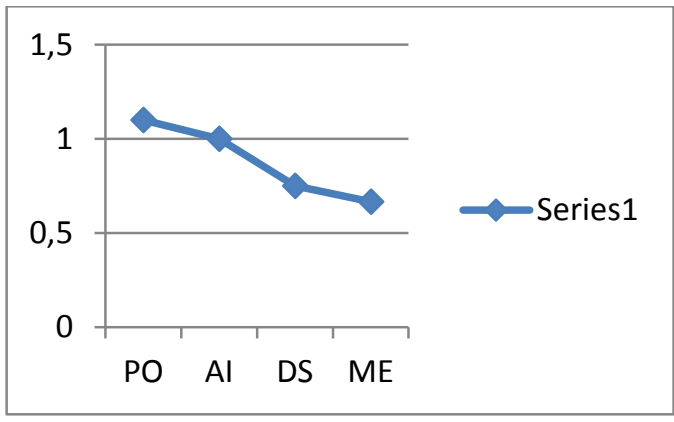

Figure 4. Maturity level graphics $P O, A I, D S, M E$

\section{CONCLUSSION}

IT supports a fraction of business processes that run DAO. If there was IT supports the business process of DAO, it was coincidentally. Results maturity Level 1 was very likely because IT has been implemented before DAO running the operational organization.

Some important notes:

1. DAO did not involve IT as part of the organization's strategic plan.

2. DAO needs have not been met by IT vice versa; IT did not provide the information needed DAO.

\section{REFERENCES}

COBIT 4.1, 2003, Executive Summary.

ITGI, 2003, Board Briefing on IT Governance,

$2^{\text {nd }}$ Edition, IT Governance Institute.

ITGI, 2007, COBIT 4.1, Framework, Control

Objectives, Management Guidelines,

Maturity Models, IT Governance Institute.

ITGI, 2006, The Val IT 2.0, Framework,

Enterprise Value: Governance of IT Investments.

Juan Ignacio Rouyet, Willem Joep Spauwen,

Luis Joyanes Aguilar, 2010, "Using

CobiT 4.1 to Achieve Business-IT

Alignment: A Practical Approach", Journal Online, ISACA Journal, Volume 1.

Prosedur UAA, 2013, Direktorat

Operasional Akademik.

Work Repot of DAO, 2013, UKRIDA

Executives Meeting 2013. 